\title{
EFEK PAPARAN PROFILIN Toxoplasma gondii TERHADAP KADAR CHEMERIN PADA TIKUS Rattus norvegicus STRAIN WISTAR
}

\author{
Agustin Iskandar ${ }^{\star \varpi}$, Dearikha Karina Mayashita**, Fathi Nabila Alim*
}

\begin{abstract}
Abstrak
Obesitas merupakan masalah kesehatan masyarakat global yang terkait dengan morbiditas, mortalitas, dan keterbatasan fungsional. Di saat yang bersamaan, prevalensi penyakit menular karena infeksi juga menunjukkan adanya peningkatan. Hal ini menimbulkan dugaan adanya keterkaitan antara infeksi dengan obesitas. Profilin merupakan bagian dari parasit Toxop/sma gondii yang dapat berikatan dengan TLR-11 dan memicu ekspresi IL-12 serta sitokin proinflamasi lain, yang diduga dapat menyebabkan obesitas. Penelitian ini bertujuan untuk mengetahui efek paparan profilin $T$. gondii terhadap kadar chemerin sebagai adipositokin proinflamasi. Penelitian ini merupakan penelitian eksperimental laboratorium dengan rancangan true eksperimental-post test only control group design, menggunakan tikus (Rattus norvegicus) strain Wistar, yang diberi dua perlakuan yakni diet normal dan diet hiperkalori. Kemudian diinjeksi profilin dosis 15, 30, $45 \mathrm{mcg} / \mathrm{mL}$. Hasil penelitian menunjukkan adanya perbedaan kadar chemerin yang signifikan $(p=0,038 ;)$. Hasil uji posthoc Tukey didapatkan perbedaan bermakna pada kelompok profilin dengan dosis $30 \mathrm{mcg} / \mathrm{mL}$ yang diberi diet hiperkalori. Uji kolerasi dan regresi linier pada kelompok diet normal menunjukkan hubungan yang kuat antara dosis profilin dengan kadar chemerin $(r=0,600)$ dan $R^{2}=0,360$ yang dapat diartikan bahwa ada pengaruh dosis profilin pada kenaikan kadar chemerin yaitu sebesar 36\%. Pada kelompok diet hiperkalori didapatkan hubungan sangat kuat antara dosis profilin dengan kadar chemerin $(r=0,078)$ dan $R^{2}=0,609$ yang berarti bahwa pengaruh dosis profilin pada kenaikan kadar chemerin sebesar $60,9 \%$. Kesimpulan penelitian ini adalah paparan profilin Toxoplasma gondii menyebabkan peningkatan kadar chemerin pada tikus strain Wistar.
\end{abstract}

Kata kunci: chemerin, obesitas, profilin, Toxoplasma gondii.

\section{THE EFFECT OF Toxoplasma gondii's PROFILIN EXPOSURE ON CHEMERIN LEVEL IN Rattus norvegicus STRAIN WISTAR}

\begin{abstract}
Obesity is a global public health problem related with morbidity, mortality and functional limitations. At the same time, the prevalence of infectious diseases due to infection also showed an increase. These suggested that there is a link between obesity and infection. Profilin is a part of the Toxoplsma gondii parasite which can bind to TLR-11 and trigger the expression of IL-12 and other proinflammatory cytokines, and allegedly can cause obesity. This study aims to determine the effect of exposure to profilin $T$. gondii on chemerin levels as proinflammatory adipocytokines. This research is a laboratory experimental study with a true experimental post-test only control group design, using rats (Rattus norvegicus) Wistar strain, which were given two treatments namely a normal diet and a hypercalory diet, then injection of profilin at a dose of 15,30 , $45 \mathrm{mcg} / \mathrm{mL}$. The results showed a significant difference in chemerin levels $(p=0.038$;). The Tukey post-hoc test found significant differences in the profilin group with a dose of $30 \mathrm{mcg} / \mathrm{mL}$ given a hypercalory diet. The correlation and linear regression tests in the normal diet group showed a strong relationship between the dose of profilin and the chemerin level $(r=0.600)$ and $R^{2}=0.360$ which can be interpreted that the effect of the dose of profilin on the increase in chemerin levels was $36 \%$. In the hypercalorie diet group, there was a very strong association between the dose of profilin and the chemerin level $(r=0.078)$ and $R^{2}=0.609$ which can be interpreted that the effect of dose profilin on the increase in chemerine levels was $60.9 \%$. The conclusion of this study is that exposure to Toxoplasma gondii profilin caused an increase in chemerin levels in Wistar rats.
\end{abstract}

Keywords: chemerin, obesity, profilin, Toxoplasma gondii.

*Departemen Parasitologi, Fakultas Kedokteran Universitas Brawijaya

** Program Studi S1 Pendidikan Dokter, Fakultas Kedokteran Universitas Brawijaya

$凶$ E-mail: agustin_almi@yahoo.co.id 


\section{Pendahuluan}

Obesitas merupakan masalah kesehatan masyarakat global yang terkait dengan morbiditas, mortalitas, dan keterbatasan fungsional, tetapi memiliki pilihan yang terbatas untuk mengintervensinya. Dalam upaya menemukan langkah baru dalam pencegahan dan intervensi, dibutuhkan penelitian lebih lanjut mengenai patogenesis dari obesitas. Secara konsisten, meningkatnya penanda inflamasi telah dilaporkan memiliki korelasi dengan obesitas. Namun, masih belum dapat diketahui bagaimana hubungan sebab-akibat antara keduanya.

Berdasarkan hasil Riskesdas pada tahun 2013, prevalensi penduduk laki-laki dewasa obesitas sebanyak 19,7 persen, lebih tinggi dari tahun 2007 (13,9\%) dan tahun $2010(7,8 \%)$, sedangkan prevalensi obesitas perempuan dewasa ( $>18$ tahun) 32,9 persen, naik 18,1 persen dari tahun 2007 (13,9\%) dan 17,5 persen dari tahun 2010 (15,5\%). Peningkatan yang signifikan ini menjadi momok tersendiri bagi bangsa indonesia, mengingat obesitas dapat memicu sejumlah penyakit kronis yang seringkali berujung pada kematian. ${ }^{1}$

Di saat yang bersamaan, prevalensi penyakit menular karena infeksi juga menunjukkan adanya peningkatan. Konsep mengenai obesitas yang dipicu oleh penyakit infeksi pertama kali disampaikan oleh Lyons pada tahun 1982 namun hanya mendapat sedikit sorotan. ${ }^{2}$ Kemudian Backhed et al. (2004), melaporkan bahwa flora normal usus meregulasi penyimpanan lemak. ${ }^{3}$ Pada penelitian lain didapatkan korelasi antara perubahan komposisi normal flora dengan kejadian obesitas. ${ }^{4}$ Dalam bidang parasit, infeksi yang diduga dapat menyebabkan obesitas adalah Toxoplasma gondii. ${ }^{5}$

Toxoplasmosis merupakan penyakit zoonosis, yakni penyakit pada hewan yang dapat ditularkan ke manusia. Penderita toxoplasmosis sering tidak memperlihatkan suatu gejala klinis yang jelas sehingga dalam menentukan diagnosis penyakit toxoplasmosis sering terabaikan dalam praktek dokter sehari-hari. ${ }^{6}$ Adanya hubungan antara serologi positif $T$. gondii dan obesitas. Individu dengan serologi positif $T$. gondii memiliki dua kali kemungkinan mengalami obese dibandingkan dengan individu seronegatif. Secara signifikan, individu dengan obese juga memiliki kadar antibodi $\lg G$ yang lebih tinggi dibandingkan individu nonobese. ${ }^{5}$

Hubungan antara $T$. gondii dengan disregulasi jaringan adiposa sudah banyak diteliti. Profilin adalah protein yang dimiliki oleh $T$. gondii yang dapat berikatan dengan TLR-11 inang kemudian memicu ekspresi IL12 dan sitokin proinflamasi lain. Penelitian sebelumnya menunjukkan adanya perbedaan kadar profilin yang bermakna antara individu obese dengan individu yang sehat. Penelitian ini juga menyebutkan bahwa peningkatan kadar profilin pada individu obese berhubungan dengan peningkatan IL-6 dan IL-12 sebagai sitokin inflamasi pada individu obese, walaupun dengan korelasi yang lemah. ${ }^{6}$ Penelitian sebelumnya juga melaporkan adanya perbedaan kadar profilin $T$. gondii, adiponektin dan omentin yang bermakna antara individu obese yang disertai sindroma metabolik dengan individu obese tanpa sindroma metabolik, tetapi tidak ditemukan perbedaan kadar insulin dan indeks resitensi insulin yang bermakna pada keduanya. ${ }^{7}$

Chemerin adalah protein kemoreaktan yang berfungsi sebagai ligan untuk reseptor chemokin-like receptor 1 (CMKLR1) dan memiliki peran dalam kekebalan adaptif. Chemerin disekresikan sebagai protein aktif $18 \mathrm{kDa}$ dan mengalami proteolisis ekstraselular pada serin protease C-terminal untuk menghasilkan $16 \mathrm{kDa}$ chemerin aktif. Konsentrasi chemerin aktif dalam plasma 
manusia sebanyak $3,0 \mathrm{nmol} / \mathrm{L}$ sedangkan pada serum manusia 4,4 nmol. Ekspresi CMKLR1 dan sekresi chemerin turut serta dalam regulasi adipogenesis. ${ }^{8}$ Chemerin dan CMKLR1 diekspresikan dalam jumlah besar pada jaringan adiposit serta ekspresi tersebut megalami up-regulation pada jaringan adiposa Pssammomys obesus, model hewan coba obesitas dan diabetes tipe 2, yang mengalami obesitas. ${ }^{9}$ Akan tetapi efek paparan profilin $T$. gondii terhadap kadar chemerin belum diketahui. Berdasarkan latar belakang tersebut, diperlukan penelitian untuk mengetahui efek paparan profilin $T$. gondii terhadap kadar chemerin pada tikus (Rattus norvegicus) strain Wistar.

\section{Bahan dan Metode}

\section{Desain Penelitian}

Penelitian ini merupakan penelitian eksperimental laboratorium dengan rancangan true eksperimental-post test only control group design yang bertujuan untuk mengetahui dan membandingkan beberapa kelompok perlakuan. Penelitian ini menggunakan tikus (Rattus norvegicus) strain Wistar pada perlakuan satu dan pada perlakuan dua dibuat model obese dengan diet hiperkalori. Penelitian dilakukan di Laboratorium Parasitologi Fakultas Kedokteran Universitas Brawijaya pada bulan februari sampai juli 2017. Penelitian ini telah mendapat persetujuan dari Komisi Etik Fakultas Kedokteran Universitas Brawijaya dengan nomor surat 134/EC/KEPK/04/2017.

\section{Sampel Penelitian}

Sampel penelitian berjumlah 35 ekor tikus Wistar jantan berusia 3-5 bulan, berat antara 50-100 gram yang diadaptasikan selama 2 minggu di Laboratorium Parasit FKUB dengan pemberian diet standar sebelum diberi perlakuan. Selanjutnya dilakukan skrining dengan kriteria inklusi sebagai berikut: a). Tikus strain Wistar sehat, b). Jantan, umur 3-5 bulan, dan c). Berat antara 50-100 gram.

\section{Kelompok Perlakuan}

Penelitian ini menggunakan 3 perlakuan, yang terdiri dari kelompok kontrol kelompok perlakuan 1 dengan dosis paparan profilin 15, 30, $45 \mathrm{mcg} / \mathrm{mL}$ serta kelompok perlakuan 2 dengan diberi hiperkalori diet dengan dosis paparan profilin sebesar 15,30 , $45 \mathrm{mcg} / \mathrm{mL}$ Tiap kelompok terdiri dari 5 ekor tikus. Pada perlakuan satu, model obese dibuat dengan cara pemberian diet hiperkalori menurut Nascimento et al., 2008. ${ }^{10}$

\section{Variabel Penelitian}

Variabel bebas dalam penelitian ini adalah pemberian profilin Toxoplasma gondii. Variabel tergantung dalam penelitian ini adalah kadar chemerin pada tikus strain Wistar.

\section{Pemeliharaan Hewan Coba dan Injeksi Profilin}

Hewan percobaan dipelihara dalam kandang yang dibersihkan setiap hari. Kandang diletakkan dalam ruangan yang berventilasi cukup dengan suhu ruangan berkisar $28-32{ }^{\circ} \mathrm{C}$. Makanan dan minuman diberikan sepuasnya (ad libitum) dalam bentuk diet standar. Pada hari pertama, keenam kelompok perlakuan diberi injeksi profilin Toxoplasma gondii secara intraperitoneal dengan dosis 15, 30, 45 $\mathrm{mcg} / \mathrm{mL}$. Tiga minggu kemudian dilakukan injeksi profilin yang kedua. Selama pemeliharaan dari hari ke-1, kelompok kontrol dan perlakuan 1 (P1) diberi diet standar, sedangkan kelompok perlakuan 2 (P2) diberikan pakan diet hiperkalori. Selama 2 minggu sekali, berat badan tikus pada semua kelompok dihitung dan dicatat. 
Pengukuran Kadar Chemerin dengan Metode ELISA

Berikutnya, tikus dibius menggunakan ketamin $50 \mathrm{mg}$ sebanyak 0,4-0,5 ml. Pembedahan tikus dilakukan untuk mengambil sampel serum darah. Darah disentrifugasi dengan kecepatan 3000 rpm selama 10 menit. kemudian diambil serumnya untuk dimasukkan ke dalam tabung eppendorf dan diisimpan dalam suhu $-20^{\circ} \mathrm{C}$. Pengukuran kadar chemerin dilakukan dengan metode ELISA menggunakan Kit Chemerin.

\section{Hasil}

Serum dikumpulkan sesuai kelompok perlakuan dan diukur menggunakan Elisa Kit Chemerin. Tabel hasil pengukuran rerata berat badan dari ketujuh kelompok perlakuan dapat dilihat pada Tabel 1.

Hipotesis awal (HO) adalah tidak terdapat pengaruh yang signifikan antara pemberian dosis paparan profilin dengan kadar chemerin. Hipotesis alternatif $(\mathrm{H} 1)$ yang diajukan yakni terdapat pengaruh yang signifikan antara pemberian dosis paparan profilin dengan kadar chemerin. Berdasar hasil uji ANOVA didapatkan nilai yang signifikan yakni $p=0,038<a=0,05$, sehingga dapat dinyatakan bahwa hipotesis H0 ditolak dan H1 diterima. Maka, terdapat perbedaan signifikan antara pemberian dosis paparan profilin dengan kadar chemerin pada sedikitnya dua kelompok perlakuan.

Hasil uji post hoc menunjukkan nilai signifikansi 0,035 pada perlakuan kontrol yang dibandingkan dengan kelompok paparan profilin dengan dosis $30 \mathrm{mcg} / \mathrm{mL}$ yang diberi diet hiperkalori menunjukkan adanya perbedaan bermakna.

Hasil uji korelasi Pearson pada kelompok perlakuan yang hanya diberi paparan profilin saja menunjukkan nilai korelasi 0,600 yang dapat diartikan terdapat hubungan yang kuat antara paparan dosis profilin dengan perubahan kadar chemerin. Nilai positif $(+)$ menunjukkan bahwa semakin besar dosis profilin yang dipaparkan maka semakin tinggi kadar chemerin. Nilai signifikansi menunjukkan 0,018 $(p<0.05)$ maka dapat dinyatakan bahwa terdapat hubungan bermakna antara perbedaan dosis paparan profilin dengan kadar chemerin.

Tabel 1. Rerata dan delta berat badan tikus.

\begin{tabular}{lcl}
\hline \multirow{2}{*}{ Kelompok } & \multicolumn{2}{c}{ Berat Badan $(\mathrm{g})$} \\
\cline { 2 - 3 } & Rerata & Delta \\
\hline Kontrol & 183 & 90,4 \\
\hline Profilin $15 \mathrm{mcg} / \mathrm{mL}$ & 189,72 & 83,40 \\
\hline Profilin $30 \mathrm{mcg} / \mathrm{mL}$ & 184,32 & 113,20 \\
\hline Profilin $45 \mathrm{mcg} / \mathrm{mL}$ & 174,56 & 70,60 \\
\hline Profilin $15 \mathrm{mcg} / \mathrm{mL}+$ Diet Hiperkalori & 234,44 & 159,4 \\
\hline Profilin $30 \mathrm{mcg} / \mathrm{mL}+$ Diet Hiperkalori & 222,2 & 149,60 \\
\hline Profilin $45 \mathrm{mcg} / \mathrm{mL}$ + Diet Hiperkalori & 222,08 & 146,2 \\
\hline
\end{tabular}

Tabel 2. Pengukuran rerata kadar chemerin.

\begin{tabular}{clc}
\hline Kelompok & Keterangan & Rerata Kadar Chemerin $(\mathrm{pg} / \mathrm{mL})$ \\
\hline 1 & Kontrol & 42,76 \\
\hline 2 & Profilin $15 \mathrm{mcg} / \mathrm{mL}$ & 47,47 \\
\hline 3 & Profilin $30 \mathrm{mcg} / \mathrm{mL}$ & 60,20 \\
\hline 4 & Profilin $45 \mathrm{mcg} / \mathrm{mL}$ & 53,07 \\
\hline 5 & Profilin $15 \mathrm{mcg} / \mathrm{mL}+$ Diet Hiperkalori & 53,54 \\
\hline 6 & Profilin $30 \mathrm{mcg} / \mathrm{mL}+$ Diet Hiperkalori & 64,25 \\
\hline 7 & Profilin $45 \mathrm{mcg} / \mathrm{mL}+$ Diet Hiperkalori & 58,01 \\
\hline
\end{tabular}


Hasil uji korelasi pada kelompok perlakuan yang diberi paparan profilin dan diet hiperkalori menunjukkan nilai korelasi 0,780 yang berarti ada hubungan yang sangat kuat antara pemberian diet hiperkalori disertai dengan paparan dosis profilin dengan perubahan kadar chemerin. Nilai positif $(+)$ menunjukkan bahwa semakin besar dosis profilin yang dipaparkan disertai pemberian diet kalori maka kadar chemerin semakin tinggi.

Berdasarkan model summary kelompok perlakuan satu, didapatkan nilai koefisien korelasi $\mathrm{R}=0,600$. Nilai ini dapat diintrepretasikan bahwa ada hubungan kuat antara dosis profilin dengan kadar chemerin yang bersifat positif. Didapatkan nilai $\mathrm{R}^{2}=$ 0,360 yang dapat diartikan bahwa pengaruh dosis paparan profilin pada kenaikan kadar chemerin sebesar $36 \%$. Sedangkan sisanya, $64 \%$ dipengaruhi oleh faktor lain diluar pemberian dosis.

Berdasarkan model summary kelompok perlakuan dua, didapatkan nilai koefisien korelasi $\mathrm{R}=0,780$. Nilai ini dapat diintrepretasikan bahwa ada hubungan sangat kuat antara dosis profilin serta pemberian diet hiperkalori dengan kadar chemerin yang bersifat positif. Didapatkan nilai $R^{2}=0,609$ yang dapat diartikan bahwa pengaruh dosis paparan profilin pada kenaikan kadar chemerin sebesar $60,9 \%$. Sedangkan sisanya, 39,1\% dipengaruhi oleh faktor lain diluar pemberian dosis dan diet hiperkalori.

\section{Pembahasan}

Toxoplasma gondii dikenal sebagai parasit patogen yang mampu menginfeksi mamalia pada sel yang berinti. ${ }^{11}$ Bagian profilin dari $T$. gondii dapat mengaktifasi TLRs dan menyebabkan infeksi. ${ }^{6}$

Chemerin adalah faktor imunomudulator atau adipositokin yang disekresi secara predominan oleh jaringan adipose dan kulit.
Selain berperan dalam homeostasis energi, adiposit juga mensekresi sitokin yang berperan dalam signaling antar sel dan dalam diferensiasi sel. Chemerin juga terlibat dalam signaling autokrin/parakrin pada proses diferensiasi adiposit, serta stimulasi lipolisis. ${ }^{12}$

Chemerin dikode oleh tazaroteneinduced gene2 (TIG2) yang juga dikenal sebagai retinois acid receptor responder gene 2 (RARRES2). Meskipun hepar dan jaringan adiposa merupakan tempat utama produksi chemerin, akan tetapi dilaporkan beberapa jaringan lain juga memproduksinya seperti kelenjar adrenal, plasenta, pankreas, paru dan kulit. ${ }^{13}$

Profilin dari $T$. gondii berikatan dengan TLR-11 yang selanjutnya akan meningkatkan sitokin proinflamasi IL-12. Kemudian sitokin proinflamasi IL-12 akan merangsang sel NK dan sel T untuk mensekresi sel fagostitik dan sel inflamasi lainnya. ${ }^{14}$ Sel NK tersebut juga mengekspresikan chemokin-like receptor 1 yang merupakan reseptor dari chemerin. Meningkatnya sitokin proinflamasi seperti IL12 merupakan pertanda awal terjadinya disfungsi adiposit. ${ }^{6}$ Keadaan inflamasi adiposit oleh sitokin proinflamasi inilah yang memicu sekresi dari chemerin. Secara umum, produksi chemerin diregulasi oleh berbagai mediator inflamatori dan metabolik yang secara umum terdiri dari: a). Agonis reseptor nuklear (retinoid, vitamin D, gluko kortikoid); b). Faktor-faktor yang berperan dalam proses metabolik (asam lemak, insulin, glukosa); dan c). Mediator imunomodulator (sitokin inflamasi akut dan kronis, lipo polisakarida). Paparan profilin T. gondii akan meningkatkan sekresi chemerin melalui mekanisme inflamasi oleh aktivasi TLRs. ${ }^{13,15}$

Berdasarkan data pengukuran chemerin pada Tabel 5 dapat diketahui bahwa kadar chemerin mengalami peningkatan pada pemberian dosis profilin 15,30 , dan 45 $\mathrm{mcg} / \mathrm{mL}$ pada perlakuan 1 maupun perlakuan 2. Pada perlakuan 1 , didapatkan kadar chemerin tertinggi pada dosis $30 \mathrm{mcg} / \mathrm{dL}$ 
kemudian diikuti oleh pemberian dosis 45 $\mathrm{mcg} / \mathrm{dL}$ dan kadar terendah pada dosis 15 $\mathrm{mcg} / \mathrm{dL}$.

Pada perlakuan 2, paparan profilin yang disertai dengan diet hiperkalori juga meningkatkan kadar chemerin. Didapatkan kadar chemerin tertinggi pada dosis 30 $\mathrm{mcg} / \mathrm{dL}$ kemudian diikuti oleh pemberian dosis $45 \mathrm{mcg} / \mathrm{dL}$ dan kadar terendah pada dosis $15 \mathrm{mcg} / \mathrm{dL}$. Hasil penelitian ini menyatakan bahwa paparan profilin mempunyai efek meningkatkan kadar chemerin pada perlakuan 1 dan perlakuan 2 .

Hasil analisis post hoc menunjukkan perbedaan yang bermakna $(p<0,05)$, hanya pada perbandingan antara kelompok kontrol dengan kelompok profilin yang diberi diet hiperkalori dengan nilai signifikansi sebesar 0,035 . Chemerin sebagai adipositokin diduga memiliki peran dalam patogenesis obesitas karena berkorelasi dengan beberapa penanda sindrom metabolik, termasuk IMT, leptin, akumulasi lemak visceral abdomen dan obesitas. ${ }^{9,16}$

Pemberian diet hiperkalori selama 14 minggu dapat meningkatkan obesitas pada tikus Wistar dan menunjukkan beberapa karakteristik yang umumnya terkait dengan obesitas manusia, seperti tekanan arterial tinggi, resistensi insulin, hiperglikemia, hiperinsulinemia, hiperleptinemia dan dislipidemia. ${ }^{10}$

Ada korelasi yang positif antara peningkatan kadar serum dengan keseluruhan regulasi adipogenesis dan peningkatan penanda inflamasi pada model hewan obesitas dan obesitas yang diinduksi diet. ${ }^{17}$ Sehingga peningkatan chemerin pada perlakuan ini dipengaruhi oleh dua faktor yakni oleh infeksi profilin $T$. gondii dan diet hiperkalori. Kedua faktor tersebut saling berkaitan dengan kejadian obese pada tikus, namun masih belum dapat dijelaskan bagaimana mekanisme keduanya hingga menyebabkan kejadian obese. Sehingga belum dapat dikonfirmasi faktor yang lebih dominan berperan terhadap peningkatan kadar chemerin.

Pada perlakuan satu tidak didapatkan perbedaan yang bermakna, hal ini dapat disebabkan oleh bias pengukuran dan aktivasi dari kadar chemerin. Chemerin disekresikan sebagai proprotein aktif $18 \mathrm{kD}$ yang diproses menjadi bentuk $16 \mathrm{kDa}$ aktif yang bertanggung jawab pada aktivitas pengikatan reseptor dan fisiologis. ${ }^{15}$ Keterbatasan pengukuran menggunakan ELISA chemerin adalah mendeteksi chemerin dalam bentuk prochemerin dan bioaktif. Maka untuk mendeteksi chemerin dalam bentuk bioaktif dilakukan Tango Assay dengan menggunakan CMKLR-1 Tango Assay, didapatkan kadar protein chemerin serum total dan tingkat chemerin bioaktif kira-kira 2 kali lipat lebih tinggi pada model tikus obesitas dibandingkan dengan tikus kontrol. Selanjutnya, konsentrasi chemerin bioaktif lebih tinggi 3 kali lipat dibanding kadar protein chemerin total dalam serum. ${ }^{18}$ Studi lain melaporkan bahwa terdapat dua macam aktivasi chemerin yakni dengan memproduksi nabati bioaktif pertama dengan aktivitas sangat rendah dan memproduksi chemerin bioaktif kedua yang diaktifkan sepenuhnya. ${ }^{19}$

Peningkatan kadar chemerin pada infeksi $T$. gondii dapat mengganggu metabolisme lemak dan kembali mencetuskan inflamasi yang mengakibatkan keadaan obese. Pada akhirnya juga akan mengganggu mekanisme glukosa uptake pada tubuh sehingga memcetuskan resistensi insulin. ${ }^{18}$

Pada penelitian ini kadar chemerin ditentukan menggunakan sampel serum sebagai indikator tunggal. Penelitian oleh Weng C, dkk (2017), terdapat perbedaan kadar chemerin pada serum, jaringan adiposa dan arteri pada hewan coba yang diberikan diet tinggi lemak. ${ }^{20}$ Peningkatan chemerin berkolerasi secara positif hanya pada pengukuran jaringan adiposa dan arteri, 
sedangkan pada serum hasilnya tidak signifikan.

Pada penelitian ini memiliki satu kelompok kontrol dan dua perlakuan yakni perlakuan satu hanya diberi infeksi profilin $T$. gondii dan perlakuan dua yang diberi infeksi profilin dan diet hiperkalori. Hal ini menyebabkan terjadinya bias kejadian obesitas antara perlakuan satu dan perlakuan dua. Belum dapat dipastikan, peningkatan chemerin pada keadaan obese disebabkan oleh infeksi profilin $T$. gondii atau akibat dari diet hiperkalori yang diberikan. Sehingga dibutuhkan penelitian lebih lanjut dengan menambahkan kelompok perlakuan yang hanya diberi diet hiperkalori saja untuk mengkonfirmasi hubungan efek paparan profilin $T$. gondii terhadap peningkatan chemerin.

T. gondii dapat diisolasi menggunakan metode inokulasi hewan laboratorium dan kultur jaringan pasien dengan sekresi, ekskresi, cairan tubuh, pengambilan jaringan melalui biopsi, dan jaringan lesi makroskopik yang diambil dari pasien post mortem. Spesimen tersebut tidak hanya digunakan untuk isolasi saja melainkan dapat dipakai untuk mendeteksi DNA $T$. gondii menggunakan teknik PCR. ${ }^{21}$ Diharapkan apabila sarana dan prasarana laboratorium telah memenuhi, agar dilakukan inokulasi hewan coba menggunakan Toxoplasma gondii dengan komponennya yang lengkap. Sehingga dapat menjelaskan mekanisme infeksi $T$. gondii terhadap kadar chemerin pada host.

\section{Kesimpulan}

Paparan profilin Toxoplasma gondii meningkatkan kadar chemerin pada tikus (Rattus norvegicus) strain Wistar baik pada pemberien diet normal hiperkalori. Injeksi profilin $30 \mathrm{mcg} / \mathrm{dL}$ dan diet hiperkalori meningkatkan kadar chemerin paling optimal dibandingkan dengan dosis 15 dan 30 $\mathrm{mcg} / \mathrm{dL}$.

\section{Saran}

Penelitian selanjutnya menggunakan chemerin di jaringan lemak sehingga dapat menggambarkan efek pemberian profilin terhadap inflamasi adiposit. Diperlukan pula penelitian lebih lanjut dengan menginokulasikan parasit T.gondii secara utuh sehingga dapat diketahui dengan jelas kaitan infeksi $T$. gondii dengan obesitas.

\section{Daftar Pustaka}

1. (Riskesdas) Riset Kesehatan Dasar. Badan Penelitian dan Pengembangan Kesehatan Kementerian $\mathrm{Rl}$ tahun. (Online). 2013. http://www.depkes.go.id/resources/downl oad/general/Hasil\%20Riskesdas $\% 20201$ 3.pdf . Diakses: 2 Oktober 2016.

2. Lyons MJ, Faust IM, Hemmes RB, Buskirk,DR, Hirsch J \& Zabriskie JB. A Virally Induced Obesity Syndrome in Mice. Science. 1982; 216:82-85.

3. Backhed F, Ding H, Wang T, Hooper LV, et al. The Gut Microbiota as An Environmental Factor that Regulates Fat Storage. Proceedings of the National Academy of Science of United States of America. 2014; 01(44):15718-15723.

4. Ley RE et al. Obesity Alters Gut Microbial Ecology. Proceedings of the National Academy of Sciences of the United States of America. 2005; 102(31):11070-11075.

5. Reeves GM, Mazaheri S, Snitker S, Langenberg P, Giegling I, Hartmann AM, et al. A Positive Association between $T$. gondii Seropositivity and Obesity. Front Public Health. 2013; 1:73.

6. Iskandar A, et al. The Level of Profilin and Interleukin-12 in Obese Patients Infected by Toxoplasma gondii: A Correlation Study Between Toxoplasma gondii 
Infection and Obesity. International Journal of Infectious Diseases. 2011; 45:361.

7. Iskandar A, Indra MR, Satuman, Firani NK, Wihastuti TA. The Levels of Toxoplasma gondii Profilin and Adiponectin in Obese Patients Complicated with or without Metabolic Syndrome as Compared to Non-Obese Patients. Asian Pacific Journal of Tropical Disease. 2016; 6(4):265-268.

8. Iskandar A., et al. The Level of Chemerin and Adipocyte Fatty Acid Binding Protein in Toxoplasma gondii Seropositive Obese Individuals. Asian Pacific Journal of Tropical Disease. 2017; 7(2).

9. Bozaoglu K, Bolton K, McMillan J, Zimmet $P$, Jowett J, Collier G, Walder K, Segal D. Chemerin is a Novel Adipokine Associated with Obesity and Metabolic Syndrome. Endocrinology. 2007; 148(10): 4687-4694.

10. Nascimento AF, et al. A Hypercaloric Pellet-Diet Cycle Induces Obesity and Comorbities in Wistar Rats. Arq Bras Endocrinol Metabol. 2008; 52(6):968-974.

11. Olgica D and Vladimir M. Murine Model of Drug-induced Reactivation of Toxoplasma gondii. Acta Protozool. 2001; 40:99-106.

12. Li Y, Shi B, Li S. Association between Serum Chemerin Concentrations and Clinical Indices in Obesity or Metabolic Syndrome: A Meta-Analysis. PLOS ONE. 2014; 9(12):e11391.

13. Mattern A, Zellmann T, Beck-sickinger AG. Processing, Signaling, and Physiological Function of Chemerin. International Union of Biochemistry and Molecular Biology Journal. 2014; 66 (1):19-26.
14. Yarovinsky F. Innate Immunity to Toxoplasma gondii Infection. Nature Reviews Immunology. 2014; 109-121.

15. Zabel BA, Kwitnewski M, Banas M, Zabieglo K., et al. Chemerin Regulation and Role in Host Defense. American Journal of Clinical and Experimental Immunology. 2014; 3(1):1-19.

16. Shin HY, Lee DC, Chu SH, Jeon JY, Lee MK, Im JA, Lee JW. Chemerin Levels are Positively Correlated with Abdominal Visceral Fat Accumulation. Clin Endocrinol. 2012; 77(1):47-50. doi: 10.1111/j.1365-2265.2011.04217.x.

17. Rourke JL, Dranse HJ, Sinal CJ. Towards An Integrative Approach to Understanding the Role of Chemerin in Human Health and Disease. Obes Rev. 2013; 14(3):24562. doi: 10.1111/obr.12009.

18. Ernst MC, Sinal CJ. Chemerin: at the Crossroads of Inflammation and Obesity. Trends in Endocrinology and Metabolism. 2010; 21(11):660-667.

19. Du XY, Zabel BA, Myles $T$, et al. Regulation of Chemerin Bioactivity by Plasma Carboxypeptidase N, Carboxypeptidase B (Activated ThrombinActivable Fibrinolysis Inhibitor), and Platelets. J Biol Chem. 2009; 284:751758.

20. Weng C, Shen Z, Li X, et al. Effects of Chemerin/CMKLR1 in Obesity-Induced Hypertension and Potential Mechanism. American Journal of Translational Research. 2017; 9(6):30963104.

21. Hill D, JP Dubey. Toxoplasma gondii: Transmission, Diagnosis and Prevention. Clinical Microbiology and Infection. 2002; 8(10):634 - 640 . 